Chapter 4

\title{
Estuarine Fisheries \\ Community-Level Response to Freshwater Inflows
}

\author{
James M. Tolan \\ Additional information is available at the end of the chapter \\ http://dx.doi.org/10.5772/52313
}

\section{Introduction}

Every estuary needs freshwater inflow (FWI) to maintain proper salinity regimes, nutrient loading, and sediment inputs to support its geographically unique levels of biological productivity [1-4]. Watershed elevations and soil types determine surface and groundwater flows into estuaries, and these flows have source, timing, and velocity components that can be significantly affected by anthropogenic alterations at the landscape level. It is estimated that approximately $60 \%$ of the global storage of freshwater is now contained behind reservoirs and dams [5] and 77\% of the total water discharge from 139 of the largest river systems in the northern hemisphere are either strongly or moderately affected by dams, interbasin transfers, and surface water withdrawals [6]. Hydrologic modifications of estuarine watersheds influence wetland and open-water salinity patterns, nutrients, sediment fertility, bottom topography, dissolved oxygen, and concentrations of xenobiotics [7]. Because demand for freshwater is only expected to increase as population continues to grow [8], it is incumbent upon resource managers to examine the environmental effects and biological consequences of hydrologic alterations within coastal ecosystems [9-11].

Resource-based approaches seek to link freshwater inflows to a number of fishery species generally considered valuable by society [12]. The optimization model utilized by Powell and Matsumoto [13] uses a series of relationships between monthly inflows and the catch of a number of commercially and recreationally important finfish (red drum Sciaenops ocellatus, black drum Pogonias cromis, spotted seatrout Cynoscion nebulosus, southern flounder Paralichthys lethostigma), crustaceans (blue crab Callinectes sapidus, white shrimp Litopenaeus setiferus, brown shrimp Farfantepenaeus aztecus, pink shrimp F. duorarum) and mollusks (eastern oyster Crassostrea virginica) to arrive at a set of targeted monthly freshwater inflows to maintain healthy ecological conditions in estuaries. The goal of this method, which jointly considers 
the salinity tolerance range of each of the target organisms and limits the inflow volume solution by imposing numerous process constraints (such as fishery biomass and harvest ratios; monthly, bi-monthly, and yearly freshwater volumes; upper and lower bounds for salinity; nutrient and sediment loading; see [13]), is to estimate the minimum amounts of FWI needed to maintain historical fisheries production. Although the inflow-harvest equations were originally based on fishery-dependent commercial catch records, recent modeling efforts have incorporated a greater proportion of fishery-independent data sources [14].

A problem with the resource-based approach is that it focuses on adults, which are harvestable. Although these are estuarine dependent species, the adults are widely distributed along salinity gradients [15]. A number of transient taxa (sensu, facultative estuarine-dependent, see [16]) which recruit from offshore spawning areas are known to have size-specific use patterns within shallow habitats of the oligohaline-to-freshwater portions of estuaries [17-20]. Inflows, especially those large pulses associated with flooding events, can displace seaward the boundary between the brackish and freshwater interface, on a kilometers-to-estuary wide scale. Taxa with specific nursery habitat requirements could therefore be restricted from ingress into portions of the estuary, potentially altering an important habitat for juvenile nekton.

The goal of this study was to expand the focus of interest of the resource-based approach beyond the limited number of fisheries target species and to include juvenile stages of fisheries species to examine the functional role of FWI in shaping the total nekton assemblage structure in estuaries. The approach was to perform an analysis of a long-term, state agency, bag seine monitoring program. Bag seine samples are fishery independent and contain juvenile stages of fishery species. There are three FWI gradients examined; within estuaries from river to sea, among estuaries along a climatic gradient, and over time as changes in freshwater inflows, in the form of flood pulses and drought events, dramatically alter the salinity structure of the estuary.

\section{Materials and methods}

\subsection{Study area}

Texas' coastline extends along $600 \mathrm{~km}$ of open Gulf of Mexico shoreline and contains 3,420 kilometers of bay-estuary-lagoon shoreline. This is a biologically rich and ecologically diverse region of the state, supporting more than 247,576 hectares of fresh, brackish, and salt marshes. Within the state, over $305,600 \mathrm{~km}$ of rivers and streams coalesce into 15 major river systems, and these rivers empty into seven major estuaries (Figure 1). All seven estuaries have similar geomorphic structure and physiography, yet each is quite diverse hydrologically. This is primarily due to a climatic gradient influencing freshwater inflows. This gradient of decreasing rainfall from northeast to southwest is one of the most distinctive features of the coastline (Table 1). Along this gradient, rainfall decreases by a factor of two, yet inflow decreases by almost two orders of magnitude. The Laguna Madre, a hypersaline lagoon, has a negative inflow balance because this estuary lacks any major riverine inflow and evapora- 
tion normally exceeds precipitation. The net effect is a gradient of estuaries with similar physical characteristics but greatly differing salinity regimes.

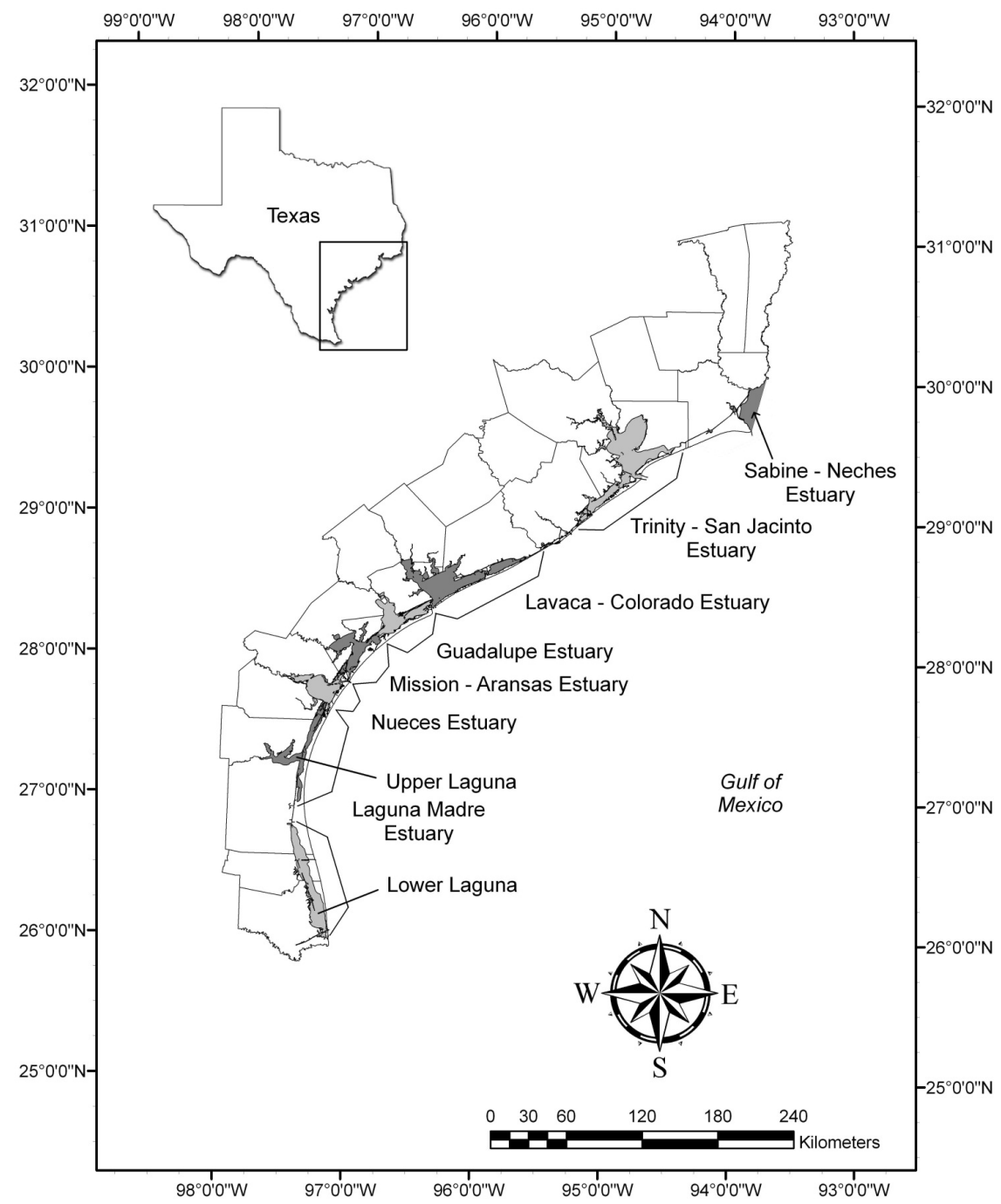

Figure 1. Map of Texas showing the location along the coast of each of the major estuarine systems. 


\begin{tabular}{|c|c|c|c|c|c|c|c|}
\hline \multirow[b]{2}{*}{ Estuary } & \multirow[b]{2}{*}{$\begin{array}{c}\text { Drainage } \\
\left(\mathrm{km}^{2}\right)\end{array}$} & \multirow[b]{2}{*}{$\begin{array}{l}\text { Area } \\
\left(\mathrm{km}^{2}\right)\end{array}$} & \multirow[b]{2}{*}{$\begin{array}{c}\text { Rainfall (cm } \\
\left.y^{-1}\right)\end{array}$} & \multirow[b]{2}{*}{$\begin{array}{c}\text { Inflow } \\
\left(10^{6} \mathrm{~m}^{3} \mathrm{y}^{-1}\right)\end{array}$} & \multirow[b]{2}{*}{$\begin{array}{c}\text { Salinity } \\
\text { (PSU) }\end{array}$} & \multicolumn{2}{|c|}{ Habitat } \\
\hline & & & & & & $\begin{array}{c}\text { Wetlands } \\
\left(\mathrm{km}^{2}\right)\end{array}$ & $\mathrm{SAV}\left(\mathrm{km}^{2}\right)$ \\
\hline Sabine-Neches & 45705 & 243 & 142 & 16897 & 8 & 967 & - \\
\hline Trinity-San Jacinto & 57900 & 1399 & 112 & 14000 & 16 & 1594 & 73 \\
\hline Lavaca-Colorado & 111890 & 1158 & 102 & 3801 & 18 & 348 & 28 \\
\hline Guadalupe & 26330 & 551 & 91 & 2664 & 16 & 271 & 65 \\
\hline Mission-Aransas & 7860 & 453 & 81 & 265 & 19 & 393 & 85 \\
\hline Nueces & 43350 & 433 & 76 & 298 & 29 & 121 & 53 \\
\hline Laguna Madre & 29695 & 3658 & 69 & -893 & 36 & 1825 & 773 \\
\hline
\end{tabular}

Table 1. Climatic gradient in Texas estuaries, listed from north to south. Drainage basin size (Drainage), bay surface area (Area), and Habitat (SAV = submerged aquatic vegetation) characteristics from USEPA (1999). Average annual Inflow Balance, Rainfall, and Salinity characteristics (1941-1999) from the Texas Water Development Board; http:// www.twdb.state.tx.us/data/bays_estuaries/bays_estuary_toc.asp

From the Louisiana border to the Trinity-San Jacinto estuary the coastline is characterized by marshy plains with low, narrow beach ridges, and from there to the border of Mexico the coastline is characterized by long barrier islands and large, shallow lagoons. Barrier islands are parallel to the mainland along the coast, and between the barrier islands and the mainland are lagoons. These lagoons are interrupted with drowned river valleys that form the bays and estuaries. Inlets through the barrier island connect the Gulf of Mexico to these lagoons, with each lagoon opening into a large primary bay. There is typically a constriction between the primary and secondary (and in some cases tertiary) bays. While ungauged coastal watershed runoff can locally influence estuarine salinity, most inflow into each bay is supplied primarily by just one or two gauged rivers draining hydrologically isolated watersheds.

\subsection{Bag seine community structure data}

Starting in January 1992 and continuing through the present, 20 replicate bag seine samples have been collected each month within each major estuary system along the Texas coast. Sampling locations are randomly selected from a grid system of one minute latitude and one minute longitude, with no selected grid sampled more than once per calendar month. For each sample, a bag seine $(18.3 \mathrm{~m}$ X $1.8 \mathrm{~m}, 1.9 \mathrm{~cm}$ stretch nylon multifilament; central bag, $1.8 \mathrm{~m}$ wide, $1.3 \mathrm{~cm}$ stretch mesh) is pulled parallel to the shore for $15.2 \mathrm{~m}$ [21]. The surface area sampled is estimated using the distance pulled and length of extension of the bag seine. All fish and invertebrates collected in each sample are identified, enumerated, and measured. Total catch of each taxon is standardized and expressed as catch per hectare. Prior to each bag seine collection, surface salinity in Practical Salinity Scale were measured with either handheld Hydrolab or YSI multiprobes calibrated to the manufacturers specifications. 


\subsection{Data analysis}

The experimental unit defined for this study was each bay system as a whole, as each of the major estuaries along the Texas coast can be defined by the underlying hydrologic gradient. To assemble the bag seine collections into a time series, catch data for each taxa from the monthly replicate samples were summed across estuaries individually, and reported as total catch per month. Salinity records were similarly transformed into a time series, although the replicate values were first averaged across each estuary and reported as mean salinity per month. For each estuary, a categorical 'Inflow Condition' variable was defined by evaluating the average salinity time series. Salinities above the $85^{\text {th }}$ percentile were deemed indicative of 'Drought' conditions and values below the $15^{\text {th }}$ percentile representative of high flow or 'Flood' conditions. Values between these two extremes were identified as 'Normal' flows. The Laguna Madre Estuary was further sub-divided into an Upper and Lower components, providing for eight estuaries under investigation (see Figure 1). This sub-division is based on a natural sand sheet or land bridge (the Land Cut) connecting Padre Island with the mainland [21]. The Gulf Intracoastal Waterway bisects this extensive sand flat, thus connecting the two lagoons via the Land Cut.

Community analyses were performed using Primer-E (Version 6.0) software [22]. A matrix of Bray-Curtis Distance similarities between each total catch per month sample was created. Catch data was initially transformed $\left[\log _{10}+1\right]$ to down-weight the most abundant taxa. Significant differences in rank similarities between groups of samples were then tested by Analysis of Similarity (ANOSIM). In the ANOSIM procedure, the probability of a priori groupings of samples is estimated by repeated permutations of the original data matrix. Values of the $R$ statistic can range from -1 to 1 , although $R$ will usually fall between 0 and 1 with $R$ values $>0.4$ indicating higher degrees of discrimination among groups. The a priori factors tested with the ANOSIM procedure were the external factors associated with each sample (e.g., season of collection and inflow condition) within a common estuary. The entire collection was then merged across estuaries, and then tested for differences in community structure among estuaries. The SIMPER (SIMilarity PERcentages) routine was used to examine the contribution of individual species to the community structure seen among the $a$ priori factors. Similarities among the samples are graphically represented with non-metric multidimensional scaling (MDS) ordinations [23]. Although outcomes of the ANOSIM are not dependant on MDS ordinations, the ordinations are presented here as they are a helpful way of visualizing patterns in the data. Stress values indicate how well the two-dimensional plot represents relationships among samples in the multidimensional space. Stress values $<0.15$ indicate a good fit. MDS ordinations may be arbitrarily rotated so axes are not labeled.

\section{Results}

From 1992 through 2006, bag seine sampling resulted in 28,786 individual collections from the eight major estuarine systems. This time series of 180 months revealed dramatically fluctuating mean salinities throughout the study period (Table 2). Despite dramatic differences 
in total inflows across the coastal hydrologic gradient, temporal inflow patterns were generally similar across the coast. The timing of extended flooding conditions (i.e., on the order of 10 months during 1992 and again in 1997) or droughts (the majority of the calendar years of 2000 and 2001) were similar within each estuary (Figure 2).

\begin{tabular}{llllll}
\hline & $n$ & Mean & Std. Dev. & Min. & Max. \\
\hline Estuary & 3599 & 6.73 & 6.23 & 0.0 & 32.0 \\
\hline Sabine-Neches & 3597 & 16.52 & 9.21 & 0.0 & 41.0 \\
\hline Trinity-San Jacinto & 3599 & 18.47 & 9.57 & 0.0 & 40.0 \\
\hline Lavaca-Colorado & 3594 & 16.62 & 11.36 & 0.0 & 45.0 \\
\hline Guadalupe & 3600 & 18.13 & 9.70 & 0.0 & 41.0 \\
\hline Mission-Aransas & 3600 & 28.66 & 7.42 & 0.0 & 59.0 \\
\hline Nueces & 3599 & 35.44 & 10.64 & 0.0 & 78.0 \\
\hline Upper Laguna Madre & 3598 & 32.04 & 7.98 & 0.0 & 64.0 \\
\hline Lower Laguna Madre & & & & & \\
\hline
\end{tabular}

Table 2. Salinity summary statistics by estuary for the study period January 1992 through December 2006.

The bag seines recorded 3,583,061 individuals from 387 unique taxa. Analysis of Similarity of the entire collection showed that in each estuary, community structure was significantly different across seasons (Table 3), and these seasonal differences were repeated annually across all inflow categories. The greatest disparity in community composition involved comparisons across opposite seasons (e.g., winter vs. summer, spring vs. fall), with significant pairwise comparison $\mathrm{R}$ values ranging from 0.609 - 0.971 (see Table 3). While seasonal differences in communities were quite evident, there appears to be little correspondence between community structure and synoptic-scale inflow events (Figure 3). This general disconnect between shallow water nekton assemblages and inflows was evident in every estuary along the Texas coast (Figure 4). The only estuaries to display significant communitylevel differences across the different inflow conditions were from opposite ends of the salinity spectrum. The Sabine-Neches estuary (mean salinity approximately 7 ) had significantly different community compositions during a drought relative to flood conditions $(\mathrm{R}=$ $0.520, p<0.001)$. Greater abundances of white shrimp (7 fold increase), brown shrimp (17 fold increase), pinfish Lagodon rhomboides (6 fold increase), white mullet Mugil curema (12 fold increase), spotted seatrout (17 fold increase), and sheepshead minnow Cyprinodon variegatus (9 fold increase) were recorded during the periods of elevated salinities. The Lower Laguna Madre (mean salinity 32) also had significantly different community compositions during drought conditions (Drought vs. Normal comparison, $\mathrm{R}=0.253, p<0.001$; Drought vs. Flood comparison, $\mathrm{R}=0.235, p<0.001)$, although the elevated salinities in this estuary during drought conditions (mean salinity $>40$ ) led to lower abundances of some of these same taxa. Substantial decreases in brown shrimp (5 fold), white shrimp (15 fold), and At- 
lantic croaker Micropogonias undulatus (7 fold), as well as lower abundances of rainwater killifish Lucania parva (4 fold decrease) and red drum (2 fold decrease) were noted during extended low inflow conditions.
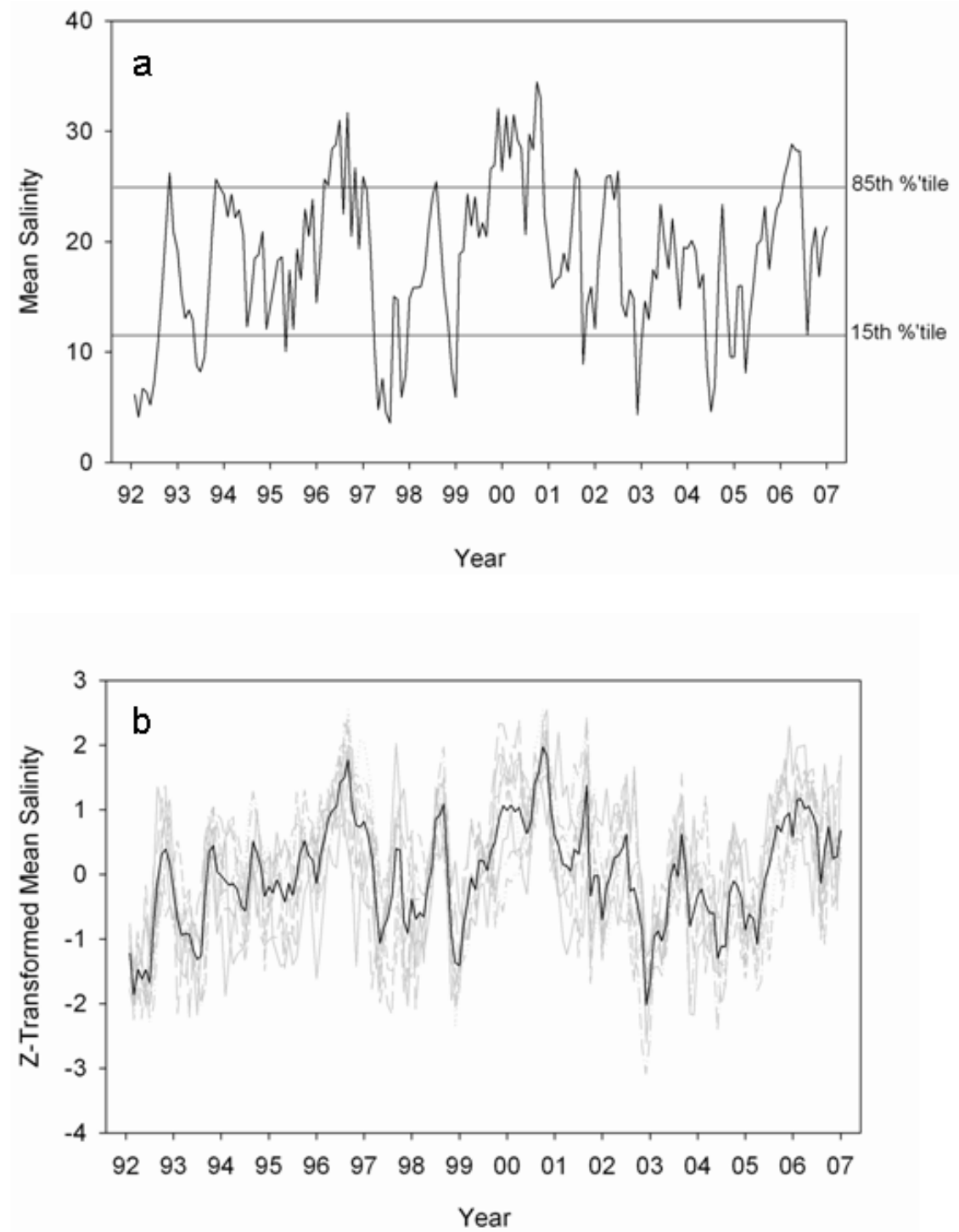

Figure 2. Estuarine-wide mean salinity time series during the study period of 1992 through 2006: (a) from a representative estuary (Lavaca-Colorado), and (b) from all eight major estuaries. Salinities in (b) are Z-transformed (not labeled individually for clarity), and a mean line added to aid in interpretation. 


\begin{tabular}{|c|c|c|c|c|c|}
\hline & Global R & & \multicolumn{2}{|c|}{$\begin{array}{l}\text { Seasonal Pairwise } \\
\text { Comparison } \mathbf{R}\end{array}$} & \\
\hline \multicolumn{6}{|l|}{ Estuary } \\
\hline & & & Winter & Spring & Summer \\
\hline & & Spring & 0.464 & - & \\
\hline \multirow[t]{3}{*}{ Sabine-Neches } & $0.669^{* * *}$ & Summer & 0.908 & 0.566 & - \\
\hline & & Fall & 0.836 & 0.834 & 0.501 \\
\hline & & Spring & 0.628 & - & \\
\hline \multirow[t]{3}{*}{ Trinity-San Jacinto } & $0.649^{* * *}$ & Summer & 0.900 & 0.553 & - \\
\hline & & Fall & 0.815 & 0.786 & 0.362 \\
\hline & & Spring & 0.576 & - & \\
\hline \multirow[t]{3}{*}{ Lavaca-Colorado } & $0.695^{\star * *}$ & Summer & 0.971 & 0.697 & - \\
\hline & & Fall & 0.820 & 0.796 & 0.391 \\
\hline & & Spring & 0.573 & - & \\
\hline \multirow[t]{3}{*}{ Guadalupe } & $0.661^{\star \star *}$ & Summer & 0.897 & 0.660 & - \\
\hline & & Fall & 0.756 & 0.786 & 0.411 \\
\hline & & Spring & 0.582 & - & \\
\hline \multirow[t]{3}{*}{ Mission-Aransas } & $0.677^{\star * *}$ & Summer & 0.848 & 0.652 & - \\
\hline & & Fall & 0.763 & 0.845 & 0.502 \\
\hline & & Spring & 0.565 & - & \\
\hline \multirow[t]{3}{*}{ Nueces } & $0.647^{\star \star *}$ & Summer & 0.802 & 0.627 & - \\
\hline & & Fall & 0.700 & 0.873 & 0.450 \\
\hline & & Spring & 0.493 & - & \\
\hline \multirow[t]{3}{*}{ Upper Laguna Madre } & $0.516^{* * *}$ & Summer & 0.651 & 0.420 & - \\
\hline & & Fall & 0.515 & 0.659 & 0.381 \\
\hline & & Spring & 0.382 & - & \\
\hline \multirow[t]{2}{*}{ Lower Laguna Madre } & $0.532^{\star \star \star}$ & Summer & 0.609 & 0.572 & - \\
\hline & & Fall & 0.629 & 0.764 & 0.302 \\
\hline
\end{tabular}

Table 3. Analysis of Similarity results of community structure within each estuary across seasons. Global R by Estuary, ${ }^{* \star *}=p<0.001$, pairwise comparison $\mathrm{R}$ values by season (significant pairwise $\mathrm{R}$ values $>$ than the Global $\mathrm{R}$ in bold). 

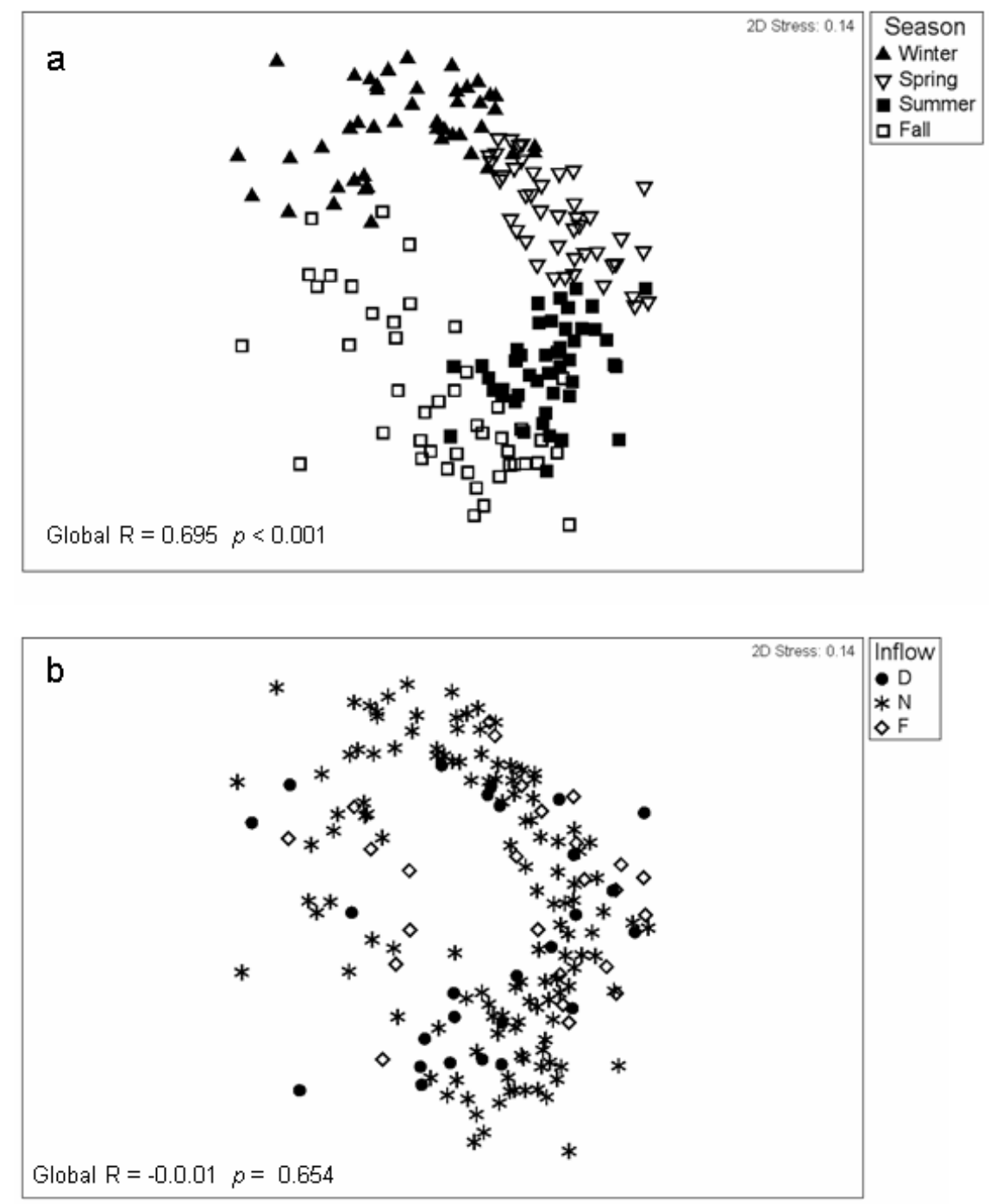

Figure 3. Multidimensional scaling (2D) configuration of bag seine community structure from a representative estuary (Lavaca-Colorado) overlaid with (a) Season, and (b) Inflow Condition. Season of collection defined as: Winter (Dec, Jan, Feb); Spring (Mar, Apr, May); Summer (Jun, Jul, Aug); and Fall (Sep, Oct, Nov). Inflow Condition designations; D = Drought, $\mathrm{N}=$ Normal, $\mathrm{F}=$ Flood. Global $\mathrm{R}$ values for each Analysis of Similarity test included. 

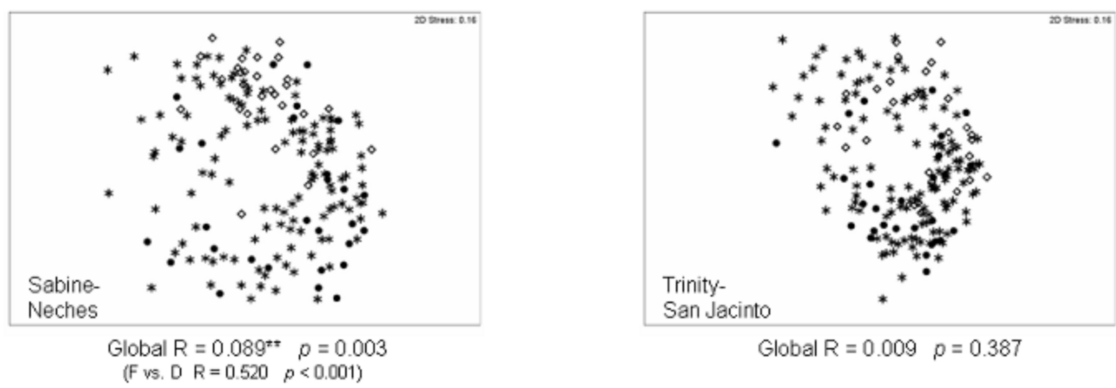

Global $R=0.009 \quad p=0.387$

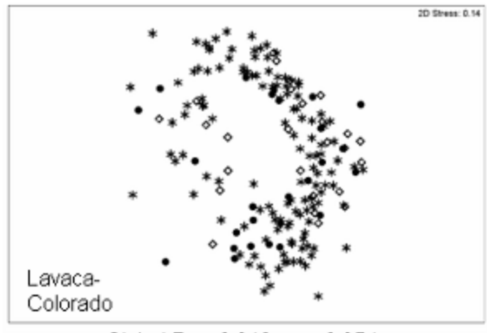

Global $R=-0.010 p=0.654$

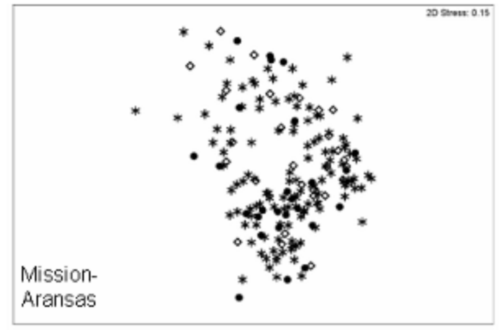

Global R $=0.033 p=0.164$

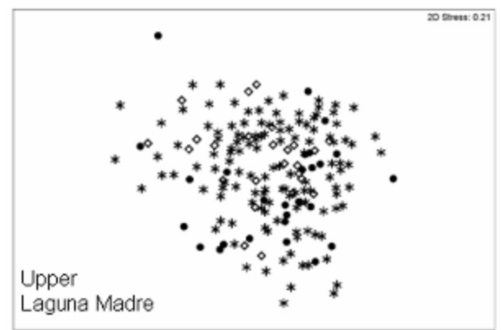

Global R $=0.031 p=0.215$

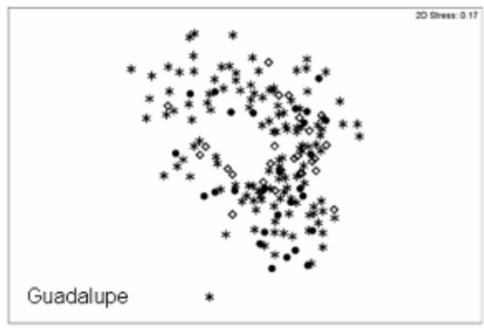

Global $R=0.018 p=0.732$

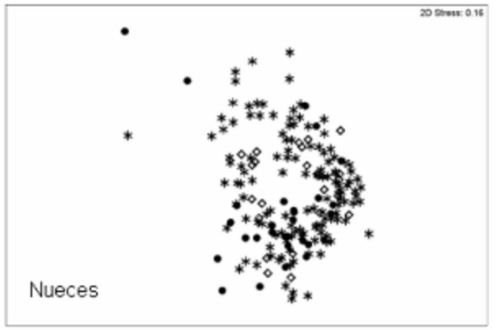

Global R $=0.005 \quad p=0.442$

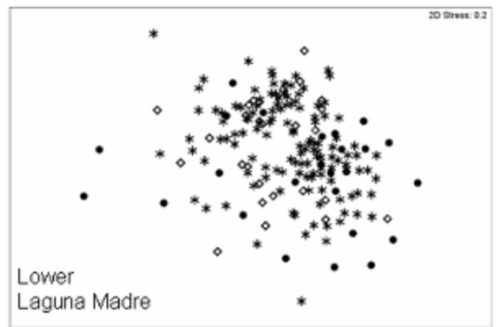

Global $R=0.156^{*} \quad p=0.002$

(D vs. N R $=0.253 p<0.001$ )

(D) vs. $F \quad R=0.235 p<0.001$ )

Figure 4. Multidimensional scaling (2D) configurations of bag seine derived community structure for each Texas estuary identifying the categorical Inflow Condition, with the Global R values for the seasonal Analysis of Similarity test. Inflow Condition symbols follow Figure 3. 
While estuary-specific assemblages do not appear to be responding to synoptic inflow events, the inclusive role of salinity on overall community structure can be seen in Table 4 . Across the estuaries, patterns of community structure roughly matched the NE-SW salinity gradient present on the Texas coast, with the freshest estuaries on the upper coast having significantly different communities than the more saline estuaries found on the lower coast. The middle coast estuaries (Lavaca-Colorado, Guadalupe, and Mission-Aransas) showed the greatest degree of overlap in their community structure. Of the hundreds of taxa that constitute the nekton recorded with the bag seines, differences among the estuaries could be explained by examining only a fraction of this total. Abundance levels of 36 taxa accounted for the vast majority of the individuals found in each estuary, ranging from a low of $99.5 \%$ in the Lavaca-Colorado system to a high of $100 \%$ in the Nueces Estuary (Table 5). Of the commercially and recreationally important species currently used for TxEMP modeling, only blue crab, white shrimp, and brown shrimp contributed substantially to nekton community structure patterns. Other taxa used for TxEMP either contributed little to the overall community (e.g., red drum ranked no higher than $12^{\text {th }}$ from any estuary; spotted seatrout no higher than $14^{\text {th }}$ ) or were identified as a characteristic component from only a single estuary (southern flounder contributed to at least 1\% of the community structure only in the SabineNeches estuary). Black drum were not identified as a significant component from any estuary. Community structure across the salinity gradient of estuaries appears to be driven by the relative proportion of only a few oligohaline (e.g., Atlantic croaker, bay anchovy Anchoa mitchilli, and Gulf menhaden Brevoortia patronus) and polyhaline to metahaline taxa (pinfish, Gulf killifish Fundulus grandis, sheepshead minnow, longnose killifish F. similis, and grass shrimp Palaemonetes spp.). Ubiquitous euryhaline taxa that were identified at equivalent ranks across the coastal salinity gradient included blue crab, striped mullet Mugil cephalus, spot Leiostomus xanthurus, brown shrimp, white shrimp, and silversides Menidia spp.

\begin{tabular}{|c|c|c|c|c|c|c|c|}
\hline Estuary & $\begin{array}{l}\text { Sabine- } \\
\text { Neches }\end{array}$ & $\begin{array}{c}\text { Trinity- } \\
\text { San Jacinto }\end{array}$ & $\begin{array}{l}\text { Lavaca- } \\
\text { Colorado }\end{array}$ & Guadalupe & $\begin{array}{l}\text { Mission- } \\
\text { Aransas }\end{array}$ & Nueces & $\begin{array}{c}\text { Upper } \\
\text { Laguna } \\
\text { Madre }\end{array}$ \\
\hline Trinity-San Jacinto & 0.299 & - & & & & & \\
\hline Lavaca-Colorado & 0.324 & 0.081 & - & & & & \\
\hline Guadalupe & 0.686 & 0.423 & 0.347 & - & & & \\
\hline Mission-Aransas & 0.555 & 0.283 & 0.213 & 0.295 & - & & \\
\hline Nueces & 0.710 & 0.371 & 0.335 & 0.418 & 0.116 & - & \\
\hline \multicolumn{8}{|l|}{ Upper Laguna } \\
\hline Madre & 0.875 & 0.806 & 0.727 & 0.403 & 0.579 & 0.679 & - \\
\hline \multicolumn{8}{|l|}{ Lower Laguna } \\
\hline Madre & 0.784 & 0.578 & 0.527 & 0.324 & 0.381 & 0.336 & 0.485 \\
\hline
\end{tabular}

Table 4. Matrix of pairwise comparison $\mathrm{R}$ values for the Analysis of Similarity test of community structure among estuaries. Global $R=0.455, p<0.001$; significant pairwise $R$ values $>$ than the Global $R$ in bold. 


\begin{tabular}{|c|c|c|c|c|c|c|c|c|}
\hline Species & $\begin{array}{l}\text { Sabine- } \\
\text { Neches }\end{array}$ & $\begin{array}{c}\text { Trinity- } \\
\text { San Jacinto }\end{array}$ & $\begin{array}{l}\text { Lavaca- } \\
\text { Colorado }\end{array}$ & $\begin{array}{c}\text { Guadalu } \\
\text { pe }\end{array}$ & $\begin{array}{l}\text { Mission- } \\
\text { Aransas }\end{array}$ & Nueces & $\begin{array}{l}\text { Upper } \\
\text { Laguna } \\
\text { Madre }\end{array}$ & $\begin{array}{c}\text { Lower } \\
\text { Laguna } \\
\text { Madre }\end{array}$ \\
\hline \multicolumn{9}{|l|}{ Micropogonias } \\
\hline undulatus & 1 & 2 & 4 & 12 & 13 & 17 & & 14 \\
\hline Callinectes sapidus* & 2 & 1 & 2 & 5 & 3 & 2 & 7 & 5 \\
\hline Anchoa mitchilli & 3 & 5 & 10 & 11 & 11 & 13 & 8 & 17 \\
\hline Brevoortia patronus & 4 & 3 & 11 & 16 & & & & \\
\hline \multicolumn{9}{|l|}{ Menidia beryllina/ } \\
\hline Mugil cephalus & 6 & 6 & & 8 & 10 & 10 & 10 & 9 \\
\hline \multicolumn{9}{|l|}{ Litopenaeus } \\
\hline setiferus* & 7 & 10 & 6 & 15 & 12 & 14 & & 13 \\
\hline Palaemonetes spp. & 8 & 7 & 1 & 1 & 1 & 6 & 3 & 12 \\
\hline \multicolumn{9}{|l|}{ Leiostomus } \\
\hline xanthurus & 9 & 8 & 9 & 9 & 8 & 7 & 11 & 6 \\
\hline \multicolumn{9}{|l|}{ Farfantepenaeus } \\
\hline aztecus* & 10 & 9 & 5 & 6 & 7 & 8 & 9 & 3 \\
\hline \multicolumn{9}{|l|}{ Lagodon } \\
\hline rhomboides & 11 & 12 & 8 & 3 & 4 & 3 & 6 & 1 \\
\hline Sciaenops ocellatus* & 12 & 16 & 15 & 14 & 14 & 16 & 16 & 18 \\
\hline \multicolumn{9}{|l|}{ Paralichthys } \\
\hline lethostigma* & 13 & & & & & & & \\
\hline Cynoscion arenarius & 14 & 17 & 18 & & & & & \\
\hline Fundulus similis & & 13 & 7 & 7 & 6 & 4 & 4 & 4 \\
\hline Fundulus grandis & & 14 & 13 & 10 & 9 & 9 & 5 & 15 \\
\hline \multicolumn{9}{|l|}{ Cynoscion } \\
\hline nebulosus* & & & & 17 & 17 & 18 & 14 & \\
\hline Gobiosoma bosc & & & & 18 & & 19 & & \\
\hline \multicolumn{9}{|l|}{ Eucinostomus } \\
\hline argenteus & & & & 19 & 18 & & & 16 \\
\hline \multicolumn{9}{|l|}{ Cyprinodon } \\
\hline variegatus & & 11 & 12 & 4 & 5 & 1 & 1 & 2 \\
\hline Mugil curema & & 15 & 14 & 13 & 15 & 15 & 15 & 11 \\
\hline \multicolumn{9}{|l|}{ Citharichthys } \\
\hline spilopterus & & 18 & 19 & & & & & \\
\hline
\end{tabular}




\begin{tabular}{|c|c|c|c|c|c|c|c|c|}
\hline Species & $\begin{array}{l}\text { Sabine- } \\
\text { Neches }\end{array}$ & $\begin{array}{c}\text { Trinity- } \\
\text { San Jacinto }\end{array}$ & $\begin{array}{l}\text { Lavaca- } \\
\text { Colorado }\end{array}$ & $\begin{array}{c}\text { Guadalu } \\
\text { pe }\end{array}$ & $\begin{array}{l}\text { Mission- } \\
\text { Aransas }\end{array}$ & Nueces & $\begin{array}{c}\text { Upper } \\
\text { Laguna } \\
\text { Madre }\end{array}$ & $\begin{array}{c}\text { Lower } \\
\text { Laguna } \\
\text { Madre }\end{array}$ \\
\hline Callinectes similis & & 19 & & & & 12 & & 10 \\
\hline \multicolumn{9}{|l|}{ Menticirrhus } \\
\hline americanus & & 20 & 16 & & & & & \\
\hline Arius felis & & 21 & 17 & & & & & \\
\hline Lucania parva & & & & & & & 12 & \\
\hline \multicolumn{9}{|l|}{ Farfantepenaeus } \\
\hline duorarum & & & & & 16 & 11 & & 7 \\
\hline Syngnathus scovelli & & & & & & & 13 & \\
\hline \multicolumn{9}{|l|}{ Percent Total } \\
\hline Abundance & 99.7 & 99.7 & 99.6 & 99.5 & 99.8 & 100 & 99.8 & 99.7 \\
\hline
\end{tabular}

Table 5. Rank order of the nekton taxa contributing to the top $90 \%$ of average similarity within each estuarine assemblage. Species identified by an asterisk $\left(^{*}\right)$ represent commercially or recreationally important target species currently used in TxEMP modeling. Blank entries represent taxa recorded from each estuary, but their overall contribution to the community in that estuary is less than $1 \%$.

\section{Discussion}

Long-term data sets are fundamental to an understanding of factors that regulate system level processes, because the inherent complexity and variability of open natural systems make it difficult to establish causal relationships between and among the important components. These data are needed to ensure that the environmental conditions which potentially can lead to dramatic fluctuations in observed nekton abundance levels are recorded at least once and preferably several times [24]. Decadal-scale continuous records of biological data utilizing uniform sampling strategies are the exception rather than the rule for most estuarine and coastal realms [25]. Many of the estuarine studies that do take into account the spatial and temporal aspects of the physical environment often utilize commercial catch and effort records [26-30], and these catch per unit effort (CPUE) indices of abundance are not without problems. Technological advances and external economic factors which can directly affect actual effort are either poorly documented, or often entirely dismissed. Circumventing some of the inherent problems associated with fishery-dependent CPUE indices, TPWD utilizes fisheries-independent sampling methodologies to assemble long-term data sets of estuarine biotic and abiotic structure [21]. Besides providing resource managers with uniform information that is reliably documented and collected under standardized sampling designs and techniques, these long-term data sets offer the antithesis to short-term management solutions dictated by monetary constraints that emphasize research and monitoring projects of limited temporal and spatial duration [31]. 
The current TxEMP methodology which uses salinity as a proxy for FWI to establish inflowspecies spatial relationships has demonstrated varying levels of correspondence between abundance and salinity gradients [14, 32-33]. In estuaries receiving substantial inflows that facilitate defined salinity zonations (e.g., Trinity-San Jacinto and Guadalupe), peak densities of many target species were spatially correlated with specific salinity zones. Conversely, in estuaries receiving lower amounts of inflows (e.g., Nueces and Laguna Madre), well defined salinity zonations were either dramatically compressed into the upper-most reaches of the estuary, or absent altogether, and consequently these same target species were far less associated with their recognized salinity preferences. Expanding the spatial scale beyond individual estuaries and using the bag seine information to encompass the entire nekton community, the present analysis shows that a much lower degree of correspondence exists between the synoptic-scale FWI signal and community assemblage. While this general lack of correspondence between the motile nekton and FWI may seem contradictory to the reported positive flow effects on fisheries abundance [29-30, 34-35], similar neutral responses by fisheries to FWI have been reported in other studies conducted at equivalent spatial scales as was used for this study. For example, in East Bay, Florida, Livingston et al. [2] found that river flow and primary production were associated mainly with changes in the communities at the lower trophic levels (herbivores and omnivore), whereas the carnivores (e.g., spotted seatrout, southern flounder, and red drum) were associated primarily with other animal trophic interactions. Their study showed that salinity changes were only indirectly involved in biological interactions at the highest trophic levels. Similarly, Griffiths [36] showed that yellowfin bream Acanthopagrus australis (the functional equivalent of pinfish used for this study) and striped mullet were generally resilient to salinity perturbations in Shellharbour Lagoon, Australia. Neutral responses to fluctuating salinities is not exclusive to finfish, as both Kimmerer [37] reporting on California bay shrimp Crangon franciscorum (functional equivalent of white shrimp) in the northern San Francisco Estuary, California, and Rozas et al. [11] working with brown shrimp in Breton Sound, Louisiana, each showed a general de-coupling of abundance levels and hydrologic conditions. Similarly, increases in temporal scales have also revealed a general de-coupling between abundance levels and FWI, as both spot and Atlantic croaker did not correlate with year-to-year variation of river discharge in Apalachicola Bay, Florida [38]. Weinstein et al. [39] also showed that shallowwater fish assemblages in the Cape Fear River estuary were not affected by annual differences in river discharge.

The repeatability of species assemblage composition and abundances from year to year across the salinity spectrum in the estuarine systems along the Texas coast is one of the most prominent features of this study. From Figure 4, it is clear that an orderly seasonal succession in abundance and species composition of the dominant components confirms the many published accounts of annually repeating community structure from a variety of locations [40-43]. A common theme found within these studies is that the identification of quite specific arrival times, or dates of first occurrence within each season of recruitment, can be shown for a number of taxa, regardless of the hydrologic conditions within an estuary at the time of recruitment. Interannual variations in these dates of first occurrence are typically small, suggesting that temporal stability of assemblage structure may be more closely relat- 
ed to temperature [40] or seasonal photoperiods than to salinity. The current analysis shows that the greatest disparity in community composition, regardless of any underlying salinity level difference, involved comparisons across opposite seasons. These seasonal differences were steadfastly replicated year after year, in spite of the dramatically different levels of freshwater inflows producing temporally unpredictable flood and drought conditions. During these environmental extremes, no wholesale changes in community composition were noted; only changes in the relative abundances within a set of common taxa.

Absent from the current analysis is a recognition of the role of physical habitat in structuring nekton community compositions (reviewed in [44]). From Table 1, it is quite clear that major differences in the areal extent of fringing wetlands and submerged aquatic vegetation exists among the eight estuaries under investigation, and despite these obvious differences, the major nekton components of each community assemblage are, for the most part, the same limited suite of taxa (Table 5). Many estuarine organisms have increased (sometimes dramatically) abundances in areas closest to the freshwater source, and these same oligo- and mesohaline areas are noted for supporting much of the wetland habitats cited in Table 1. Even though the direct effect that FWI has on wetlands and the species that use them has not been definitely demonstrated [12], there is very good evidence that these relationships exist, at least for some size-groups or life history stages [7, 18, 36, 45]. Transient groups of young-of-the-year clupeiforms (Gulf menhaden, bay anchovy), perciforms (Atlantic croaker, spot, red drum, pinfish, spotted seatrout, and both species of mullets) and pleuronectiforms (southern flounder, bay whiff) that are spawned in deeper estuarine, nearshore, or offshore waters have all been shown to enter the shallow portions of estuaries and occur in very high densities in their recruitment and residence periods [17-19, 34,47]. Those nekton communities from the fresher, upper coast estuaries with large amounts of surrounding wetlands supported greater proportions of Atlantic croaker, bay anchovy, Gulf menhaden, and striped mullet than did the more southern estuaries with less fringing marsh. In the more saline estuaries, where seagrasses generally replace fringing marsh systems as one of the dominant structured habitats, the nekton communities identified by the bag seines were characterized by increases in cyprinidontiforms (sheepshead minnows and longnose killifish), grass shrimp, pinfish. Except for pinfish, all these taxa are estuarine-residents that do not recruit from nearshore or offshore spawning grounds, therefore the intermediate linkage between freshwater inflows and physical habitats may not be as important for these populations to be successful.

Many investigations have suggested that variability in estuarine production can be attributed either directly or indirectly to the fertilizing effects of freshwater input [1, 10, 48-49]. This estuarine 'agricultural model' is based on a mechanistic link between nutrient loading and increased phytoplankton production, ultimately leading to increased fisheries yields. Although Sutcliffe's [48] arguments have been disputed on interpretation and statistical grounds $[46,50]$, the concept persists and is fundamental to the implementation of the TxEMP methodology. Relating the flow effects to animal populations requires trophic transfer up the food web, and numerous studies have focused on the relative importance of 'topdown' vs. 'bottom-up' control of aquatic food webs [51-54]. A distinct dichotomy in the 
response of FWI controlling factors within estuarine systems appears to be that the herbivores and omnivores are more directly linked to physical and chemical controls associated implicitly with primary production ('bottom-up' regulation), whereas the carnivores (primary, secondary, and tertiary) are more closely associated with 'top-down' biological factors $[2,38]$. Examination of the target taxa used for the TxEMP inflow-species relationships (Table 5) shows that all the vertebrates fall into the tertiary carnivore class, and the epibenthic macroinvertebrates are classified by as primary and secondary carnivores [2]. Omnivorous taxa that are more likely to have a more direct trophic linkage to the effects of FWI included pinfish, spot, striped mullet, white mullet, hardhead catfish Arius felis, and Gulf pipefish Syngnathus scovelli. Spot, a bottom-feeding perciform characteristic of the assemblage structure in every estuary, are potentially an important linkage between inflows and production because of their ability to regulate benthic invertebrates [55]. The connection between the benthos and FWI associated production appears show a much stronger mechanistic link [38, 56-57], although the benthic environment is represented only by eastern oyster within the current modeling paradigm. Thus, evaluating the biological effects of FWI within Texas estuaries is currently dependent upon taxa that empirically have been shown to display the weakest mechanistic couplings.

The time steps involved in TxEMP FWI modeling are on the order of a calendar month, whereas the nekton appear to be operating on the order of months (the seasonal signal was clearly evident in every estuary across the coast) to a calendar year (the repeating pattern of seasonal compositions common to each estuary resulted in the circular configuration of the samples seen in Figure 3a). Conversely, the drought and flood FWI signal common to the entire Texas coast is due by climate-level drivers operating at fundamental frequencies of approximately 11, 5, and 3.5 years [58]. While all of the commercially and recreationally important finfish used to quantify optimal FWI are long lived species and can contribute a number of different year-classes to the nekton community, the macroinvertebrates used by TxEMP all have life spans less than even the shortest frequency inflow signal driver. The shrimp species are all considered annual species [15], with maximum life spans from 18 months to 2 years, whereas blue crabs are reported to have a life span approaching 3 years. For the shrimp species abundant throughout the Texas coast, physical timing of their recruitment periods appear to be more in synchrony with species-specific temperature ranges instead of estuarine salinity requirements. Brown shrimp recruit to the estuary from February through May, while white shrimp typically show up from June through October. Once recruited from offshore spawning areas, white shrimp juveniles can migrate farther into the less saline waters of the upper estuary because they are more tolerant of lower salinities than the other shrimp species. This pattern is evidenced by the higher rank abundance values for white shrimp seen in the less saline upper coast estuaries, whereas rank values for brown shrimp were higher in the more saline lower coast estuaries. While the interaction of available habitat and salinity tolerance levels can therefore aid in successful recruitment, the annual frequency in shrimp spawning does not appear to be closely tied to the multiyear to decadal frequencies of the inflows. These observations conform to the conclusions of Allen and Barker [19], in that 'responses of populations to major changes in the estuarine environ- 
ment are more strongly expressed as alterations in the magnitude than in the timing of habitat utilization'.

Because estuarine fishes have evolved to exploit one of the more physiologically challenging environments, it should not too surprising that they do not appear to be dramatically responding to the synoptic-scale inflow events that are currently used to quantify 'ecological health'. Even when utilizing species ranks to adjust for any gross differences in relative abundance among estuaries (e.g., biomass), the present analysis reveals that in each estuary, the contributions of a very limited number of taxa were strikingly similar. To evaluate the functional role of freshwater inflow into estuaries and determine estuarine FWI needs for the future, incorporating more sensitive 'measuring stick' organisms are recommended. One way this could be accomplished is to incorporate a greater range of trophic structure, utilizing some of the lower trophic level taxa that constituted a majority portion of the community assemblage (e.g., Gulf menhaden, bay anchovy, Gulf killifish, striped mullet, sheepshead minnow), or base the FWI modeling on taxa that appear to show a definite salinity response (e.g., Atlantic croaker, longnose killifish, white mullet, pinfish). Still another more challenging option would be to move down the trophic food web and index measures of 'estuarine health' to benthic taxa that show more direct mechanistic linkages to FWI.

\section{Acknowledgements}

I am sincerely indebted to the more than twenty years of field staff and technicians at the Coastal Fisheries Division of Texas Parks and Wildlife Department for their diligent collection of the biotic and abiotic parameters used for this study. This project was never explicitly funded by research grants, but I gratefully acknowledge the continued support of Sportfish Restoration Funds, without which the time for data synthesis and interpretation would not have been possible.

\section{Author details}

James M. Tolan*

Address all correspondence to: james.tolan@tpwd.state.tx.us

Texas Parks and Wildlife Department, Coastal Fisheries Division, Natural Resource Center 2501, Unit 5846, Corpus Christi, TX, USA

\section{References}

[1] Flint, R.W. Long-term estuarine variability and associated biological response. Estuaries 1985;8 158-169. 
[2] Livingston, R.J., N. Xufeng, F.G. Lewis, III, and G.C. Woodsum. Freshwater input to a Gulf estuary: long-term control of trophic organization. Ecological Applications $1997 ; 7$ 277-299.

[3] Logeragan, N.R., and S.E. Bunn. River flows and estuarine ecosystems: implications for coastal fisheries from a review and case study of the Logan River, southeast Australia. Australian Journal of Ecology 1999;24 431-440.

[4] Alber, M. A conceptual model of estuarine freshwater inflow management. Estuaries 2002;25 1246-1261.

[5] Vörösmarty, C.J., and D. Sahagian. Anthropogenic disturbance of the terrestrial water cycle. BioScience 2000;50 753-765.

[6] Dynesius, M., and C. Nilsson. Fragmentation and flow regulation of river systems in the northern third of the world. Science 1994;266 753-762.

[7] Sklar, F.H., and J.A. Browder. Coastal environmental impacts brought about by alterations to freshwater flow in the Gulf of Mexico. Environmental Management 1998;22 $547-562$.

[8] Rijsberman, F.R. Water scarcity: Fact or fiction? Agricultural Water Management 2006;80 5-22.

[9] Skreslet, S. Freshwater outflow in relation to space and time dimensions of complex ecological interactions in coastal waters. In: S. Skreslet (ed.) The role of freshwater outflow in coastal marine ecosystems. Berlin, Germany: Springer-Verlag; 1986. p3-12.

[10] Mallin, M.A., H.W Paerl, J. Rudek, and P.W. Bates. Regulation of estuarine primary productivity by watershed rainfall and river flow. Marine Ecology Progress Series 1993;93 199-203.

[11] Rozas, L.P., T.J. Minello, I. Munuera-Fernandez, B. Fry, and B. Wissel. 2005. Macrofaunal distributions and habitat change following winter-spring releases of freshwater into the Breton Sound estuary, Louisiana (USA). Estuarine, Coastal and Shelf Science 65:319-336.

[12] Longley, W.L., editor. Freshwater inflows to Texas bays and estuaries: Ecological relationships and methods for determination of needs. Texas Water Development Board and Texas Parks and Wildlife Department, Austin, Texas. 1994.

[13] Powell, G.L., and J. Matsumoto. Texas estuarine mathematical programming model: a tool for freshwater inflow management. In: K.R. Dyer and R.J. Orth (eds.) Changes and fluxes in estuaries. Fredensborg, Denmark: Olsen and Olsen; 1994. p401-406.

[14] Pulich, W. Jr, J. Tolan, W.Y. Lee, and W. Alvis. Freshwater inflow recommendation for the Nueces Estuary. http://www.tpwd.state.tx.us/landwater/water/conservation/ freshwater_inflow/nueces/ (accessed 20 Feb 2010).

[15] Patillo, M.E., T.E. Czapla, D.M. Nelson, and M.E. Monaco. Distribution and abundance of fishes and invertebrates in Gulf of Mexico estuaries, Volume II: Species life 
history summaries. ELMR Report Number 11. NOAA/NOS Strategic Assessment Division, Silver Spring, MD. 1997.

[16] Able, K.W. A re-examination of fish estuarine dependence: Evidence for connectivity between estuarine and ocean habitats. Estuarine, Coastal and Shelf Science 2005;64 5-17.

[17] Weinstein, M.P., and H.A. Brooks. Comparative ecology of nekton residing in a tidal creek and adjacent seagrass meadow: community composition and structure. Marine Ecology Progress Series 1983;12 15-27.

[18] Rogers, S.G., T.E Targett, and S.B. Van Sant. Fish-nursery use in Georgia salt-marsh estuaries: the influence of springtime freshwater conditions. Transactions of the American Fisheries Society 1984;113 595-606.

[19] Allen, D.M., and D.L. Barker. Interannual variation in larval fish recruitment to estuarine epibenthic habitats. Marine Ecology Progress Series 1990;63 113-125.

[20] Hare, J.A., and K.W. Able. Mechanistic links between climate and fisheries along the east coast of the United States: explaining population outbursts of Atlantic croaker (Micropogonias undulatus). Fisheries Oceanography 2007;16 31-45.

[21] Martinez-Andrade, F., P. Campbell, and B. Fuls. Trends in relative abundance and size of selected finfishes and shellfishes along the Texas Coast: November 1975-December 2003. Management Data Series No. 232, Texas Parks and Wildlife Department, Coastal Fisheries Division. Austin, Texas. 2005.

[22] McKee, D.A. Fishes of the Laguna Madre: A guide for anglers and naturalists. College Station, Texas: Texas A\&M University Press. 2008.

[23] Clarke, K.R., and R.M. Warwick. Change in marine communities: an approach to statistical analysis and interpretation, 2nd edition. Plymouth : PRIMER-E. 2001.

[24] Kruskal, J.B. Multidimensional scaling by optimizing goodness of fit to a non-metric hypothesis. Psychometrika 1964;29 1-27.

[25] Rose, K.A., and J.K. Summers. Relationships among long-term fisheries abundances, hydrographic variables, and gross pollution indicators in northeastern U.S. estuaries. Fisheries Oceanography 1992;1 281-293.

[26] Wolfe, D.A., M.A. Champ, D.A Flemer, and A.J. Mearns. Long-term biological data sets: their role in research, monitoring, and management of estuarine and coastal marine systems. Estuaries 1987;10 181-193.

[27] Summers, J.K., T.T. Polgar, J.A. Tarr, K.A. Rose, D.G. Heimbuch, J. McCurley, R.A. Cummins, G.F. Johnson, K.T. Yetman, and G.T. DiNardo. Reconstruction of longterm time series for commercial fisheries abundance and estuarine pollution loadings. Estuaries 1985;8 114-124.

[28] Pearson, T.H., and P.R.O. Barnett. Long-term changes in benthic populations in some west European coastal areas. Estuaries 1987;10 220-226. 
[29] Houde, E.D., and E.S. Rutherford. Recent trends in estuaries fisheries-predictions of fish production and yield. Estuaries 1993;16 161-176.

[30] Jassby, A.D., W.J. Kimmerer, S.G. Monismith, C. Armor, J.E. Cloern, T.M. Powell, J.R. Schubel, and T.J. Vendlinski. Isohaline position as a habitat indicator for estuarine populations. Ecological Applications 1995;5 272-289.

[31] Diop, H., W.R. Keithly, Jr., R.F. Kazmierczak, Jr., and R.F. Shaw. Predicting the abundance of white shrimp (Litopenaeus setiferus) from environmental parameters and previous life stage. Fisheries Research 2007;86 31-41.

[32] Champ, M.A. Monitoring: Painting a moving train. Sea Technology 1986;27 73.

[33] Pulich, W. Jr, J. Tolan, W.Y. Lee, and W. Alvis. Freshwater inflow recommendation for the Nueces Estuary. http://www.tpwd.state.tx.us/landwater/water/conservation/ freshwater_inflow/nueces/ (accessed 20 Feb 2010).

[34] Tolan, J.M., W.Y. Lee, G. Chen, and D. Buzan. Freshwater inflow recommendation for the Laguna Madre Estuary system. Texas Parks and Wildlife Department. Austin, Texas. 2004.

[35] Copeland, B.J. Effects of decreased river flow on estuarine ecology. Journal of the Water Pollution Control Federation 1966;38 1831-1839.

[36] Weinstein, M.P., and M.P. Walters. Growth, survival and production in young-ofyear populations of Leiostomous xanthurus Lacépéde residing in tidal creeks. Estuaries 1981;4 185-197.

[37] Griffiths, S.P. Factors influencing fish composition in an Australian intermittently open estuary. Is stability salinity-dependent? Estuarine, Coastal and Shelf Science 2002;52 739-751.

[38] Kimmerer, W.J. Effects of freshwater flow on abundance of estuarine organisms: physical effects or trophic linkages? Marine Ecology Progress Series 2002;243 39-55.

[39] Kobylinski, G.J., and P.F. Sheridan. Distribution, abundance, feeding and long-term fluctuations of spot, Leiostomus xanthurus, and croaker, Micropogonias undulates, in Apalachicola Bay, Florida, 1972-1977. Contributions in Marine Science 1971;22 149-161.

[40] Weinstein, M.P., S.L. Weiss, and W.F. Walters. Multiple determinants of community structure in shallow marsh habitats, Cape Fear River estuary, North Carolina, USA. Marine Biology 1980;58 227-243

[41] McGovern, J.C., and C.A. Wenner. Seasonal recruitment of larval and juvenile fishes into impounded and non-impounded marshes. Wetlands 1990;10 203-221.

[42] Witting, D.A., K.W. Able, and M.P. Fahay. Larval fishes of a Middle Atlantic Bight estuary: assemblage structure and temporal stability. Canadian Journal of Fisheries and Aquatic Sciences 1999;56 222-230. 
[43] Hagan, S.M., and K.W. Able. Seasonal changes of the pelagic fish assemblage in a temperate estuary. Estuarine, Coastal and Shelf Science 2003;56 15-29.

[44] Tolan, J.M. Larval fish assemblage response to freshwater inflow: a synthesis of five years of ichthyoplankton monitoring within Nueces Bay, Texas. Bulletin of Marine Science 2008;82 275-296.

[45] Minello, T.J. Nekton densities in shallow estuarine habitats of Texas and Louisiana and the identification of essential fish habitat. In L. Benaka (ed.) Fish habitat: Essential fish habitat and habitat restoration. American Fisheries Society, Symposium 22. Bethesda, MD. 1999. p43-75.

[46] Sinclair, M., G.L. Bugden, C.L. Tang, J.C. Therriault, and P.A. Yeats. Assessment of effects of freshwater runoff variability on fisheries production in coastal waters. In S. Skreslet (ed.) The role of freshwater outflow in coastal marine ecosystems. Berlin, Germany: Springer-Verlag. 1986. p139-160.

[47] Martino, E.J., and K.W. Able. Fish assemblage across the marine to low salinity transition zone of a temperate estuary. Estuarine, Coastal and Shelf Science 2003;56 969-987.

[48] Sutcliffe, W.H., Jr. Some relation of land drainage, particulate matter, and fish catch in to eastern Canadian bays. Journal of the Fisheries Research Board of Canada 1972;29 357-362.

[49] Cloern, J.E., A.E. Alpine, B.E. Cole, R.L.J Wong, J.F. Arthur, and M.D. Ball. 1983. River discharge controls phytoplankton dynamics in the northern San Francisco Bay estuary. Estuarine, Coastal and Shelf Science 1983;16 415-429.

[50] Drinkwater, K.F., and R.A. Myers. Testing predictions of marine fish and shellfish landings from environmental variables. Canadian Journal of Fisheries and Aquatic Sciences 1987;44 1568-1573.

[51] McQueen, D.J., R.S. Johannes, J.R. Post, T.J. Stewart, and D.R.S. Lean. Bottom-up and top-down impacts on freshwater pelagic community structure. Ecological Monographs 1989;59 289-309.

[52] Menge, B.A. Community regulation: under what conditions are bottom-up factors important on rocky shores. Ecology 1992;73 755-765.

[53] Flinkman, J., E. Aro, I. Vuorinen, and M. Viitasalo. Changes in northern Baltic zooplankton and herring nutrition from 1980s to 1990s: top-down and bottom-up processes at work. Marine Ecology Progress Series 1998;165 127-136.

[54] Micheli, F. Eutrophication, fisheries, and consumer-resource dynamics in marine pelagic ecosystems. Science 1999;285 1396-1398.

[55] Killam, K.A., R.J. Hochberg, and E.C. Rzemiem. Synthesis of basic life histories of Tampa Bay species. Tampa Bay National Estuary Program, Technical Publication Number 10-92. 1992. 
[56] Nilsson, P., B. Jönsson, I.L. Swanberg, and K. Sundbäck. Response of a marine shallow-water sediment system to an increased load of inorganic nutrients. Marine Ecology Progress Series 1991;71 275-290.

[57] Montagna, P.A., and R.D. Kalke. The effect of freshwater inflow on meiofaunal and macrofaunal populations in the Guadalupe and Nueces Estuaries. Estuaries 1992;15 307-326.

[58] Tolan, J.M. El Nino-Southern Oscillation impacts translated to the watershed scale: salinity patterns along the Texas Gulf Coast, 1982 to 2004. Estuarine, Coastal and Shelf Science 2007;72 247-260. 